\section{Objections to Japan's system}

\section{Tokyo}

SuCCESSFul applicants for big grants are usually the last people to complain of unfairness in the grant selection process. But it seems the Japanese are different: this year, more than a few of the justannounced winners in the competition for Japan's most lucrative basic research grants are ready with criticism of the way they were selected. And they find their opinions echoed by the handful of foreigners who have just encountered Japanese peer review under the Human Frontier Science Program.

Much of the criticism is directed at the large 'special distinguished' and 'priority' grants of the Ministry of Education, Science and Culture (see below). These million-dollar grants run for three to five years. Special distinguished grants are awarded to about ten individuals each year and are intended to support "internationally recognized research that is likely to produce outstanding results". The priority grants support research by large teams of scientists and about 20 are awarded each year.

The grant applications are screened by small committees of academics selected by the ministry's science council, a group of prominent academics and industrialists. After initial screening, potential candidates are summoned to the ministry for interview by one of three committees specializing in biology, literature, and physics, chemistry and engineering. The interview lasts about 20 minutes with a 10 to 15 -minute presentation by the applicant followed by questions.

One recipient of a special distinguished grant said he was "deeply depressed" when he entered the room for his interview and discovered that there was no-one among the ten committee members with expertise in his field of research. He said it was clear from their questions that the committee members did not really understand what he wanted to do. He was also dismayed that the committee chairmen wielded so much control over the proceedings and questioning.

The recipient suspects his application was successful only because he happened to have met two of the committee members previously, and because he was able to produce an article praising his work that had been published in a foreign journal. But in the absence of such evidence of international recognition, he says it is easy to see how the committee could make mistakes.

A member of the ministry's science council defends its methods, saying that a researcher with a good proposal should be able to present its aims clearly to intelligent non-specialists. And in his opinion, while the committees may have dropped good proposals they have never made mistakes in those selected.

But some members of the ministry's grant selection committees think the process could be improved. One solution that has received support is to widen the scope of opinion by involving some foreign experts in the selection of grants.

Another recipient of a priority grant described the selection process as "feudalistic", with a few prominent academics scattering grants among people with a wide range of ability from "aristocrats to peasants". He further complains that many of the recipients are people nearing retirement who seem to have been given awards as a sort of "golden handshake". But he says the grant system has improved in recent years. In the past, recipients of these big grants were chosen by prominent academics without competition. But now anyone can apply. This, however, has created another problem.

Only about one in ten applicants
JAPAN's biggest grants for basic research this year go to the study of protein kinase $\mathrm{C}$ and cancer. Research on the global environment, neurocomputing and stellar formation also feature prominently in this year's 'special distinguished' and 'priority' grants announced by Japan's Ministry of Education, Science and Culture.

The special distinguished grants just announced, which go to individuals, begin immediately. But the priority grants which support large teams of scientists do not begin until next fiscal year and thus their size is still subject to negotiations with the Ministry of Finance. Nevertheless, the amount of funds that the researchers applied for gives a good indication of final grant size.

Yasutomi Nishizuka of Kobe University School of Medicine gets the biggest special distinguished grant with an award of $¥ 330$ million ( $\$ 2.4$ million) over four years to continue his internationally recognized research on protein kinase C. Kumao Toyoshima seems set to get the biggest priority grant with his request for $¥ 2,400$ million ( $\$ 18$ million) over four years for work on the mechanism of cancer, including oncogenes and viruses. Toyoshima will head a huge team of about 100 researchers divided into 35 or 36 groups. Shunichi Amari, a mathematician at Tokyo University who has developed key parts of the theory behind neural networks models, is also listed for a large priority grant. His team has requested $¥ 1,433$ million ( $\$ 10$ million) over five years to develop a theory of informationprocessing in the brain with the ultimate succeed and those who fail receive no explanation of why their application was rejected. This is in contrast to the grant systems in the United States, for example, where grant applications are sent to expert referees for comment.

The same criticism has been made by Western scientists of Japan's new Human Frontier Science Program. Last year, the Ministry of International Trade and Industry (MITI) launched a 'pilot' Frontiers programme and solicited applications for five international grants from scientists of the Western summit nations and European Communities. But MITI received more than 40 applications and did not explain to the many unsuccessful applicants why their proposals were rejected. According to Japanese scientists involved in the project, several Western scientists were "furious" about the lack of explanation.

A Japanese academic adviser for Frontiers says the system will be revised to accommodate these complaints when the full-scale programme is launched at the end of this month.

David Swinbanks

\section{aim of building a neurocomputer.}

Osamu Nishikawa of Rissho University's department of geography has requested $¥ 694$ million over three years to develop a computer system to model the effects of Japan's modernization on the global environment. And Kei Takeuchi of Tokyo University's Research Center for Advanced Science and Technology requests $¥ 799$ million for five years to try to dream up socio-economic systems for the twentyfirst century that will allow economic growth for developing countries and yet at the same time will protect the environment and natural resources through the utilization of 'environment-friendly' leading-edge technology.

One of the biggest special distinguished grants ( $¥ 307$ million for four years) goes to Yasuo Fukui of Nagoya University who will use a new 4-metre radio telescope to observe the detailed carbon-monoxide spectra of interstellar gas during the process of star formation.

In addition to awards for internationally recognized research, the ministry has awarded special distinguished grants for research well out of the mainstream. Taizo Masumi of Tokyo University gets $¥ 144$ million to pursue his belief that there is a relationship between photoconductivity and superconductivity in the new hightemperature superconductor materials. And Akimasa Masuda of the same university is awarded $¥ 214$ million to search for two as yet undiscovered isotopes of technetium, a radioactive element with an atomic number of 43 .

David Swlnbanks 